\title{
SYNTHETIC, STRUCTURAL, MAGNETIC AND TGA STUDIES OF SOME COPPER COMPLEXES OF HETEROCYCLIC LIGANDS
}

\author{
J. M. Barabde*, N. R. Agrawal , G. D. Thorat and G. B. Pethe \\ Department of Chemistry, Sant Gadge Baba Amravati University, \\ Amravati-444 602
}

\begin{abstract}
Solid complexes of $\mathrm{Cu}$ (II) with substituted Isonicotinamide ligands derived from substituted triazoles have been synthesized and have been characterized by elemental analysis, molar conductance, IR, ${ }^{1} \mathrm{H}-\mathrm{NMR}$ and UV spectra and TG analysis and Probable structures are assigned to the complexes. Physicochemical data suggest octahedral geometry to $\mathrm{Cu}(\mathrm{II})$ complexes. The IR spectra of the ligands and their complexes are used to identify the type of bonding. The TG analysis of ligands and their $\mathrm{Cu}(\mathrm{II})$ complexes have been carried out.
\end{abstract}

KEYWORDS: 1 , 2, 4- Triazole , Cu(II) complexes, Magnetic, TGA, biological Studies

\section{INTRODUCTION}

Heterocyclic compound are very important in field of medicinal Chemistry ${ }^{1}$. Nitrogen based Heterocyclic compound are very important in field of medicinal Chemistry they have very good biological activities ${ }^{2}$, 3. Azoles are important five membered heterocyclic rings containing at least one nitrogen atom like Isoxazole, Thiazole, Pyrazole and Triazole 4-6. $1,2,4$-triazole is more important because it is the basis of best modern agricultural fungicides as well as drugs for fungal disease in humans $\mathbf{7}$. The importance of metal complexes of 1,2,4- Triazole amide in academic commercial and pharmacological fields provoked our interest in the coordination chemistry of 1,2,4-Triazole. This has led to systematic study of $\mathrm{Cu}$ (II) metal complexes of 1,2,4-traizle4-yl isonicotinamide derived from substituted Oxiadiazole and isonicotinic acid hydrazide. The therapeutic effects of 1,2,4-triazole and 1,2,4-triazole 3-one containing compound have been well studied for a no of pathological condition 
including cancer, pain, tuberculosis or hypertension ${ }^{\mathbf{8}}$. Copper II ions is a biologically active in chelating ability and biologically transport reaction $\mathrm{Cu}(\mathrm{II})$ complex possess wide range of biologically activity and are among the most potent antiviral, antitumor and antiflammatary agents $\mathbf{6}, \mathbf{8}$. In the present work, four isonicotinamide ligand and their copper complex have been prepared and characterised.

\section{Method:}

All the chemical use as starting material for synthesis of the ligand and their metal complexes were A.R. grade or chemically pure solvents were purified and dried before use by literature method. The ligand used in the present work were not commercially available hence were synthesized in our laboratory. These newly synthesized ligands were characterised by IR, ${ }^{1} \mathrm{H}$ NMR. The following four ligands have been synthesized.

Synthesis of ligands.

1. N- (3-phenyl)- 5(4-methoxyphenyl)- 4H-1,2,4-triazole -4 yl ) isonicotinamide . $\mathrm{L}_{1}$

2. $\mathrm{N}$-(3-(2-chloroyphenyl)-5(4-methoxyphenyl)-4H-1,2,4-triazole -4 yl)isonicotinamide. $\mathrm{L}_{2}$

3. N-(3-(4-methoxyphenyl)-5-(4-nitrophenyl)-4H-1,2,4-triazole-4yl )isonicotinamide. $\mathrm{L}_{3}$

4. $\mathrm{N}$ - (3,5bis (4-methoxyphenyl)-4H-1,2,4-triazole -4 yl ) isonicotinamide. $\mathrm{L}_{4}$

\section{Preparation of $L_{1}, L_{2}, L_{3}$ and $L_{4}$}

A mixture of substituted 1,3,4-oxadiazole (0.01 mole) and isoniazid (0.01 mole) in dry pyridine $(10 \mathrm{ml})$ was refluxed for $6-8 \mathrm{hr}$. The reaction mixture was cooled to room temperature and then the contents were poured on to crushed ice and neutralized with dilute $\mathrm{HCl}$ solution. The resulting solid was dried and crystallized from glacial acetic acid. The scheme is as shown in fig. 


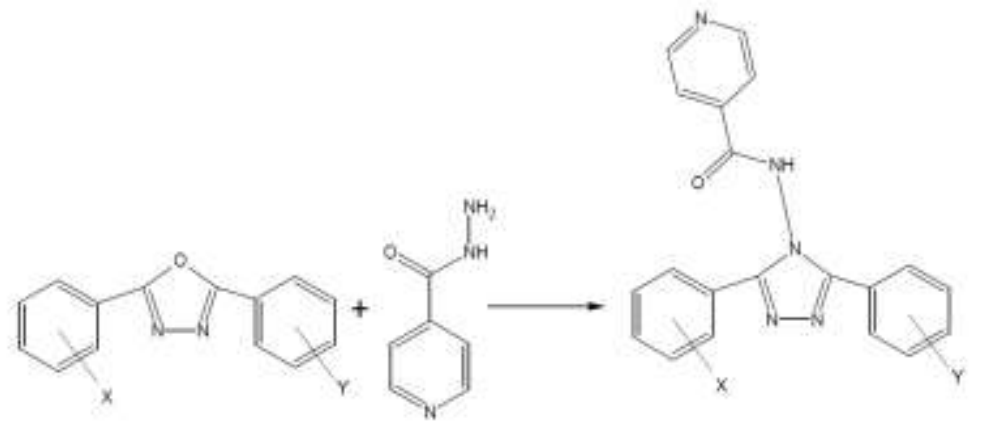

\begin{tabular}{|l|l|l|}
\hline \multicolumn{1}{|c|}{ Compound } & \multicolumn{1}{|c|}{ X } & \multicolumn{1}{c|}{$\mathrm{Y}$} \\
\hline L1 & $-\mathrm{H}$ & $4-\mathrm{OMe}$ \\
\hline L2 & $2-\mathrm{Cl}$ & $4-\mathrm{OMe}$ \\
\hline L3 & $4-\mathrm{OMe}$ & $4-\mathrm{NO}_{2}$ \\
\hline L4 & $4-\mathrm{OMe}$ & $4-\mathrm{OMe}$ \\
\hline
\end{tabular}

\section{${ }^{1} \mathrm{H}$ NMR spectra of data of ligands}

The value following by the number of protons nature of peak and group cantoning protons in parenthesis are given for each ligand

Ligand ( $\left.\mathrm{L}_{1}\right)$ :-N- (3-phenyl)- 5(4-methoxyphenyl)- 4H-1,2,4-triazole -4 yl ) isonicotinamide show the following pick

1. $\delta 7.3(\mathrm{~s}, 1 \mathrm{H}, \mathrm{NH})$

2. $\delta 7.6-7.8(\mathrm{~m}, 9 \mathrm{H}$, aromatic $)$

3. $\delta 8.1-8.8(\mathrm{~m}, 4 \mathrm{H}$, hetero-aromatic)

4. $\delta 3.9\left(\mathrm{~s}, 3 \mathrm{H}, \mathrm{OCH}_{3}\right)$

Ligand $\quad\left(\mathrm{L}_{2}\right)$ :- $\quad \mathrm{N}$-(3-(2-chloroyphenyl)-5(4-methoxyphenyl)-4H-1,2,4triazole-4 yl)isonicotinamide.

1. $7.34(\mathrm{~s}, 1 \mathrm{H}, \mathrm{NH})$

2. $\delta 7.1-8.0(\mathrm{~m}, 8 \mathrm{H}$,aromatic)

3. $\delta 7.8-8.88(\mathrm{~m}, 4 \mathrm{H}$, hetero-aromatic)

4. $\delta 3.9\left(\mathrm{~s}, 3 \mathrm{H}, \mathrm{OCH}_{3}\right)$ 
Ligand(L $\left.\mathrm{L}_{3}\right)$ :-N-(3-(4-methoxyphenyl)-5-(4-nitrophenyl)-4H-1,2,4-triazole$4 y 1$ )isonicotinamide.

1. $\delta 7.34(\mathrm{~s}, 1 \mathrm{H}, \mathrm{NH})$

2. $\delta 7.1-8.2(\mathrm{~m}, 8 \mathrm{H}$, aromatic)

3. $\delta 8.2-8.8(\mathrm{~m}, 4 \mathrm{H}$, hetero-aromatic)

4. $\delta 3.9\left(\mathrm{~s}, 3 \mathrm{H}, \mathrm{OCH}_{3}\right)$

Ligand (L4):- N- (3,5bis (4-methoxyphenyl)-4H-1,2,4-triazole -4 yl ) isonicotinamide

1. $\delta 7.2(\mathrm{~s}, 1 \mathrm{H}, \mathrm{NH})$

2. $\delta 7.5-8.12(\mathrm{~m}, 8 \mathrm{H}$, aromatic)

3. $\delta 8.41-8.8(\mathrm{~m}, 4 \mathrm{H}$,hetero-aromatic)

4. $\delta 3.9\left(\mathrm{~s}, 6 \mathrm{H}, \mathrm{OCH}_{3}\right)$

\section{Synthesis of complexes}

Metal salts cupric nitrate $(0.01 \mathrm{~mole})$ and the ligands $(0.02 \mathrm{~mole})$ of the dissolved separately in ethanol $(25 \mathrm{ml})$ and DMF-ethanol $(1: 4 \mathrm{v} / \mathrm{v}, 25$ $\mathrm{ml}$ ) respectively. Both the solution were filtered and mixed in hot condition. The reaction mixture was refluxed for 4-6 $\mathrm{hr}$ in a water bath. The coloured product obtained was filtered, washed several times with hot water followed by ethanol and diethyl ether and finally dried over fused calcium chloride.

\section{PHYSICAL MEASUREMENTS}

The estimation of carbon, hydrogen and nitrogen were obtained on a Carlo-Erba $1108 \mathrm{C}-\mathrm{H}-\mathrm{N}$-analyser at micro analytical unit SAIF, CDRI, Luknow. The IR spectra were recorded in $\mathrm{KBr}$ pellets on a Perkin-Elmer1600 FT-IR spectrophotometer. The reflectance spectra of the complexes were recorded on a Carry-2390 spectrophotometer using $\mathrm{BaSO}_{4}$ as a dilutant and $\mathrm{MgO}$ as a reference in the range $200-1500 \mathrm{~nm}$ at SAIF, IIT 
Chennai. ${ }^{1} \mathrm{H}-\mathrm{NMR}$ spectrum of the ligand was recorded in a mixed solvent $\left(\mathrm{CDCl}_{3}+\mathrm{DMSO}\right)$ on a bruker AC-200F, 300MHZ, NMR spectrometer using TMS as an internal standard at RSIC- Punjab university, Chandigarh. Magnetic measurements were carried out at room temperature using Gouy's method using $\mathrm{Hg}$ [Co (SCN) $\left.{ }_{4}\right]$ as calibrant and values were corrected for diamagnetism by using Pascal's constant. Thermogravimetric analyses of the complexes were carried out using a TGS-2Perkin Elmer thermal analyzer in the temperature range $50-700{ }^{\circ} \mathrm{C}$ at a heating rate of $10{ }^{\circ} \mathrm{C} \mathrm{min}^{-1}$. Antibacterial and antifungal activities of the ligand and their complexes were carried out against the bacteria $E$. coli and $S$. aureus by cup plate method.

\section{RESULTS AND DISCUSSION}

The required 1,3,4-oxadiazoles prepared by refluxing a mixture of substituted benzohydrazide and substituted benzoic acid in phosphorus oxychloride for 4-6 hours. Then these oxadiazolesm were refluxed with isoniazide in dry pyridine. The ligands were confirmed on the basis of IR, NMR and nitrogen analysis. The physical characterization and micro analytical data of ligands and its coordination complexes are given in (Table 1).

\section{IR Spectra}

The IR spectra of the ligand were recorded for the identification of their donor sites in frequencies after their complexation with metal ion. The Partial listing of the IR spectra of the ligand is given in Table 2 the entire ligand exhibit following assignment.

1. A medium sharp absorption band around at $3290-3180 \mathrm{~cm}^{-\mathbf{1}}$ is assigned to $\mathrm{N}-\mathrm{H}$ stretching vibration of $\mathrm{NH}$ group of the ligands. 9

2. A strong absorption band at $1685-1665 \mathrm{~cm}^{-1}$ is due to $\mathrm{C}=\mathrm{O}$ (amide) stretching frequency 10,11

3. A strong absorption band at $1617-1603 \mathrm{~cm}^{-1}$ is assigned to $\mathrm{C}=\mathrm{N}$ (imine) streatching vibration 10, 11 . 
4. A medium band at $1535-1480 \mathrm{~cm}^{-1}$ may be assigned to $\mathrm{C}-\mathrm{O}$ phenolic stretching vibration ${ }^{12-14}$

5. A weak band appearing at $1070-1060 \mathrm{~cm}^{-1}$ is attributed to pyridine ring breathing vibration 15 .

6. A weak band at $1000-990 \mathrm{~cm}^{-1}$ is assigned to $\mathrm{N}-\mathrm{N}$ stretching vibration 15 .

7. Table 1: The Proposed composition, formula weight, colour, Thermal data and Magnetic moment of Ligands and its $\mathrm{Cu}(\mathrm{II})$ Complexes

\begin{tabular}{|c|c|c|c|c|c|c|c|c|c|c|c|}
\hline $\begin{array}{l}\mathrm{Sr} \\
\text {.no }\end{array}$ & Ligand & $\begin{array}{c}\text { M.P./ } \\
\text { Half } \\
\text { DecompTemp } \\
{ }^{0} \mathrm{C}\end{array}$ & $\begin{array}{c}\text { Yield } \\
(\%)\end{array}$ & $\begin{array}{l}\text { Molecular } \\
\text { Formula }\end{array}$ & $\begin{array}{c}\text { Formula } \\
\text { Weight }\end{array}$ & Colour & $\mathrm{C} \%$ & $\mathrm{H} \%$ & $\mathrm{~N} \%$ & M \% & $\begin{array}{c}\text { Magnetic } \\
\text { Moment } \\
\text { in B.M. }\end{array}$ \\
\hline 1. & $\mathrm{~L}_{1}$ & 158 & 65 & $\mathrm{C}_{21} \mathrm{H}_{17} \mathrm{~N}_{5} \mathrm{O}_{2}$ & 371.36 & Creamish & $\begin{array}{c}69.22 \\
(67.90) \\
\end{array}$ & $\begin{array}{c}4.48 \\
(4.69)\end{array}$ & $\begin{array}{c}19.36 \\
(18.86)\end{array}$ & -- & -- \\
\hline 2. & $\mathrm{~L}_{2}$ & 218 & 60 & $\mathrm{C}_{21} \mathrm{H}_{16} \mathrm{ClN}_{5} \mathrm{O}_{2}$ & 405.36 & Creamish & $\begin{array}{c}61.26 \\
(62.64) \\
\end{array}$ & $\begin{array}{c}3.49 \\
(3.97) \\
\end{array}$ & $\begin{array}{c}17.98 \\
(17.27) \\
\end{array}$ & -- & -- \\
\hline 3. & $\mathrm{~L}_{3}$ & 235 & 58 & $\mathrm{C}_{21} \mathrm{H}_{16} \mathrm{~N}_{6} \mathrm{O}_{4}$ & 416.390 & Yellow & $\begin{array}{c}61.38 \\
(60.52) \\
\end{array}$ & $\begin{array}{c}3.96 \\
(3.84) \\
\end{array}$ & $\begin{array}{c}20.79 \\
(20.17) \\
\end{array}$ & -- & -- \\
\hline 4. & $\mathrm{~L}_{4}$ & 222 & 62 & $\mathrm{C}_{22} \mathrm{H}_{19} \mathrm{~N}_{5} \mathrm{O}_{3}$ & 401.361 & $\begin{array}{c}\text { Pale } \\
\text { yellow }\end{array}$ & $\begin{array}{c}66.02 \\
(65.06) \\
\end{array}$ & $\begin{array}{c}4.12 \\
(4.74) \\
\end{array}$ & $\begin{array}{c}18.06 \\
(17.70) \\
\end{array}$ & -- & -- \\
\hline 5. & $\begin{array}{c}\mathrm{Cu} \\
\mathrm{L}_{1} \text { Complex }\end{array}$ & 378 & 58 & $\mathrm{Cu}\left[\mathrm{C}_{42} \mathrm{H}_{36} \mathrm{~N}_{10} \mathrm{O} 6\right]$ & 839.92 & Blue & $\begin{array}{c}59.23 \\
(60.32)\end{array}$ & $\begin{array}{c}4.12 \\
(4.73)\end{array}$ & $\begin{array}{c}15.25 \\
(16.67)\end{array}$ & $\begin{array}{c}7.25 \\
(7.69)\end{array}$ & 1.87 \\
\hline 6. & $\begin{array}{c}\mathrm{Cu} \\
\mathrm{L}_{2} \text { Complex }\end{array}$ & 392 & 62 & $\begin{array}{l}\mathrm{Cu}\left[\mathrm{C}_{42} \mathrm{H}_{34}\right. \\
\left.\mathrm{Cl}_{2} \mathrm{~N}_{10} \mathrm{O}_{6}\right]\end{array}$ & 909.92 & Green & $\begin{array}{c}53.92 \\
(55.55)\end{array}$ & $\begin{array}{c}4.06 \\
(3.77)\end{array}$ & $\begin{array}{c}14.26 \\
(15.03)\end{array}$ & $\begin{array}{c}5.52 \\
(6.93)\end{array}$ & 1.86 \\
\hline 7. & $\begin{array}{c}\mathrm{Cu} \\
\text { L3Complex }\end{array}$ & 400 & 54 & $\mathrm{Cu}\left[\mathrm{C}_{42} \mathrm{H}_{34} \mathrm{~N}_{12} \mathrm{O}_{10}\right]$ & 930.34 & Green & $\begin{array}{c}54.93 \\
(54.22)\end{array}$ & $\begin{array}{c}3.64 \\
(3.68)\end{array}$ & $\begin{array}{c}18.25 \\
(18.07)\end{array}$ & $\begin{array}{c}6.68 \\
(6.83)\end{array}$ & 1.81 \\
\hline 8. & $\begin{array}{c}\mathrm{Cu} \\
\mathrm{L}_{4} \text { Complex }\end{array}$ & 294 & 64 & $\mathrm{Cu}\left[\mathrm{C}_{44} \mathrm{H}_{40} \mathrm{~N}_{10} \mathrm{O}_{8}\right]$ & 900.05 & Green & $\begin{array}{c}57.26 \\
(58.53)\end{array}$ & $\begin{array}{c}3.26 \\
(4.44)\end{array}$ & $\begin{array}{c}16.46 \\
(15.51)\end{array}$ & $\begin{array}{c}6.89 \\
(7.03)\end{array}$ & 1.82 \\
\hline
\end{tabular}

Table 2: IR Spectral data $\left(\mathrm{cm}^{-1}\right)$ of the Ligands and $\mathrm{Cu}(\mathrm{II})$ metal complexes.

\begin{tabular}{|c|c|c|c|c|c|c|c|}
\hline Sr.no & Ligand & $v(\mathbf{N}-\mathrm{H})$ & $v(C=0)$ & $v(C=N)$ & $v(M-N)$ & $v\left(\mathrm{H}_{2} \mathrm{O}\right)$ & $v(C-O)$ \\
\hline 1. & $\mathrm{~L}_{1}$ & 3215 & 1719 & 1585 & -- & -- & 1220 \\
\hline 2. & $\mathrm{~L}_{2}$ & 3211 & 1722 & 1569 & -- & -- & 1232 \\
\hline 3. & $\mathrm{~L}_{3}$ & 3209 & 1732 & 1576 & -- & -- & 1305 \\
\hline 4. & $\mathrm{~L}_{4}$ & 3214 & 1735 & 1557 & -- & -- & 1292 \\
\hline 5. & $\mathrm{Cu} \mathrm{L}_{1}$ Complex & -- & -- & 1596 & 425 & 3360,789 & 1221 \\
\hline 6. & $\mathrm{Cu} \mathrm{L}_{2}$ Complex & -- & -- & 1588 & 436 & 3446,860 & 1295 \\
\hline 7. & Cu L $\mathrm{L}_{3}$ Complex & -- & -- & 1578 & 466 & 3376,834 & 1292 \\
\hline 8. & $\mathrm{Cu} \mathrm{L}_{4}$ Complex & -- & -- & 1566 & 467 & 3387,898 & 1236 \\
\hline
\end{tabular}




\section{Electronic spectra and magnetic studies}

The magnetic moments for $\mathrm{Cu}$ (II) complexes are given in Table 1. at room temperature corresponding to one unpaired electron. The electronic spectrum of $\mathrm{Cu}$ (II) complex displayed band at 16478$16562 \mathrm{~cm}^{-1}$ as signed for the ${ }^{2} \mathrm{~T} 2 \mathrm{~g} \rightarrow{ }^{2} \mathrm{E}_{\mathrm{g}}$ transition. The electronic transitions and magnetic moment value suggests pseudo octahedral geometry around $\mathrm{Cu}$ (II) ion 16-18. A detailed interpretation of the electronic spectra of $\mathrm{Cu}$ (II) complexes is rather complicated owing to distorted octahedral which is very common in $\mathrm{Cu}$ (II) complexes which give strong charge transfer bands telling off in the blue end of the visible spectrum.

\section{Thermogravimetric analysis}

In the present investigation, analysis of TG curves of ligands and its $\mathrm{Cu}$ complexes reveals a two stage decomposition pattern. All the $\mathrm{Cu}$ complexes are almost stable upto $70-80^{\circ} \mathrm{C}$. The $\mathrm{Cu}$ complexes loss their weight in the range $180-230{ }^{\circ} \mathrm{C}$ corresponding to two coordinated water molecules. The $\mathrm{Cu}$ (II) complexes show a gradual but continuous weight loss between $265-645^{\circ} \mathrm{C}$ due to oxidative thermal degradation of ligand. The final stage ends with the arial oxidation of the complexes and formation of respective stable metal oxide. The thermal decomposition temperature is as shown in Table 1.

\section{Conclusion:}

All the complexes are coloured solids, air stable and are having line solubility in polar solvents DMF and DMSO. The elemental analyses shown in Table 1 indicate that all these complexes have 1:2 metal: ligand stoichiometry and were in good agreement with the values calculated from proposed formula. 


\section{ACKNOWLEDGEMENT}

The authors wish to thank SAIF Chandigarh and CDRI Lucknow for recording elemental analyses, IR, NMR, electronic spectra and Sant Gadge Baba Amravati University, Amravati for providing the laboratory facility.

\section{REFERENCES}

Aliya B., Sireesha C.H., Reddy V.R. and Devi S., J Ind. Chem Soc.; 85 : 926-929.

Roy R.U., Desai A R. and Desai K.R., (2005). E-journal of Chemistry; 6(2), 23-28.

Catarzi D., Colotta V., Varano F., Cecchi L., Filacchnioni G., Galli A., Costagli C. and Carla V., (2000). J. Med Chem .; 43: 3824-29.

Talwar M.B., Laddi V.V., Somannavar Y.S., Benner, R.S., and Bennur. S. C, (1945). Indian J Heterocyclic Chem, 4: 297-299.

Prasanna M.K. and Pradeep K.K., (2013). Int J Pharm Biomed Sci.; 4(1) : 24-28.

Omar F.A., Mahfour N.M. and Rahman M.A., (1996). Eur J. Med. Chem,; 52: 819-825.

Claydon, Greeves, Warren, and Wothers, Organic Chemistry, 1168

Yar M. S., Siddiqui. A. A. and Ali A., (2007). J. Chinese Chem. Soc,,; 54: 5-8.

Lal R.A., Pal M.L., Chakraborty J., and Kumar A., (2000), Ind. J Chem., 39(A) : 1194-1198.

Maurya M.R. and Gopinathan. C., (1996). Indian J chem., 35(A) : 702125.

Maurya M.R. Antony, D.C. Gopinathan S., Puranik, U.G., Tavale S.S. and Gopinathan C., (1995). Bull. Chem. Jpn.; 68 : 2847-2849. 
Jayaramadu M. and Reddy K.H., (1999). Ind. J Chem., 38 (A) : 11731175.

Reddy P.M., Kumar K.A., Raju K.M. and Murthy N.M., (2000). Ind. J Chem.; 39(A) : 1182-1184.

Dey K., Chakrabarty K., Bhattacharya P.K., Bandopadhyay D., Nag S.K., and Bhowniick R., (1999). Ind. J. Chem.; 38(A): 1139-43.

Agrawal R. K., Agrawal H. and Prasad, R., (1996). J. Ind. Chem. Soc.; 73 : 605-607.

Byers W., Lever A.B.P and Parish, R.V., (1968). Inorg Chem.; 7 : 1835-41.

Cotton F.A. and Wikinsion G., (1966). Advanced Inorganic Chemistry, $2^{\text {nd }} \mathrm{Ed}$ Interscience,901-906.

Karayananisnis N.M., Mukulsk C.M., Pytleuski L.L. and Labes M.M., (1965). J. Inorrg and Nucl Chem., 34 : 3139-44. 